University of Nebraska - Lincoln

DigitalCommons@University of Nebraska - Lincoln

Agronomy \& Horticulture -- Faculty Publications

Agronomy and Horticulture Department

$1-1927$

\title{
Some Ecological Aspects of Agriculture in The Prairie
}

J. E. Weaver

University of Nebraska-Lincoln

Follow this and additional works at: https://digitalcommons.unl.edu/agronomyfacpub

Part of the Plant Sciences Commons

Weaver, J. E., "Some Ecological Aspects of Agriculture in The Prairie" (1927). Agronomy \& Horticulture -Faculty Publications. 468.

https://digitalcommons.unl.edu/agronomyfacpub/468

This Article is brought to you for free and open access by the Agronomy and Horticulture Department at DigitalCommons@University of Nebraska - Lincoln. It has been accepted for inclusion in Agronomy \& Horticulture -Faculty Publications by an authorized administrator of DigitalCommons@University of Nebraska - Lincoln. 


\begin{tabular}{lll}
\hline \hline Vol. VIII & NANUARY, I927 I \\
\hline
\end{tabular}

\title{
SOME ECOLOGICAL ASPECTS OF AGRICULTURE IN THE
} PRAIRIE ${ }^{1}$

\author{
J. E. WeAver \\ University of Nebraska
}

It is of more than passing interest that the cereal crops, namely: corn, spring and winter wheat, oats, barley, sorghum, and millet, have their center of greatest production in that portion of the United States originally covered by grassland. In fact, some are grown almost entirely in the grassland region, and other crops, as alfalfa and flax, which are similar in growth habits to wild legumes, wild flaxes, etc., growing among the grasses, also have their greatest acreage in grassland. Likewise, the largest areas of fruit production, including such tree fruits as apples, peaches, pears, and bush fruits as blackberries, currants, and raspberries, are in those portions of the United States formerly occupied by native species of similar habits, i.e., forest trees and shrubs.

It is my purpose to consider some phases of crop production in this great mid-continental area and to interpret them in the light of the prairie vegetation and the conditions which have controlled its development.

The agricultural productivity of any region is conditioned on four series of factors, namely: the climate, the topography and soil, the adapted crops, and the adequacy of cultivation. The highest productivity exists where under a favorable climate and soil adapted crops are adequately cultivated.

\section{Climate}

The climate of this vast area, although far from uniform, is distinctly favorable to the growth of various kinds of grasses and unfavorable to the development of forests or other woody vegetation. An exception to this general statement occurs in the more humid, eastern portion where, because of poor drainage, fires, or other causes which have delayed the development of the forest climax, grasses occupy potential forest land.

Notwithstanding the wide range of this rather uniform topographic area

1 Invitation paper presented at the meeting of the Ecological Society of America, Kansas City, Mo., December, I925.

[Ecology, Vol. VII, No. 4 (pp. 39I-523) was issued October 21, 1926.] 
latitudinally, the most important climatic factor is precipitation. This varies from about 40 inches in the most humid Illinois section to about 12 inches in the drier Montana grasslands. Most of the precipitation falls during the growing season when the vegetation can utilize the larger portion of it. Moreover, the soils, not being leached at other seasons, retain their productivity better than those of more humid sections. Hence, where the precipitation is only 25 to 30 inches annually, the high productivity of the unleached soils just about balances the defect of frequently deficient rainfall. In fact approximately 70 to 80 per cent of the precipitation in the grassland area occurs during the six warmer months of the year.

The difference in the amount of the precipitation is the controlling factor in limiting the distribution of the several plant associations which are grouped regionally and constitute the grassland formation. As already mentioned, much of the grassland in the better watered states, especially Illinois, Iowa, and Missouri, is potential forest land, but was, until cultivated, occupied by the subclimax grasses. The climax tall-grass prairie covers approximately the eastern one third of the Dakotas, Nebraska, and Kansas, and large areas in Oklahoma, as well as portions of Minnesota, Iowa, and Missouri. Mixed prairie occupies central Nebraska and Kansas and practically the entire remaining northern and western portion of the grassland area. Here the tall grasses of the east meet and mingle on more or less equal terms with the short grasses of the drier plains. The short-grass plains occupy extensive areas in the south and west, that is, in western Nebraska, Kansas, and Oklahoma, eastern Colorado, northwestern Texas, and northern New Mexico (Clements, '20, Shantz, '23). Each of these climax grassland communities is limited in extent by rather definite climatic conditions which also exert a profound effect upon crop production.

The average winter temperatures (December-February) over the grassland area vary, generally speaking, rather uniformly from $45^{\circ} \mathrm{F}$. across central Texas to $10^{\circ} \mathrm{F}$. across central North Dakota. They are really of minor importance, except in the case of fall sown cereals, since they occur during the non-growing season. Differences in the average summer temperature (June to August) vary from $80^{\circ} \mathrm{F}$. across southern Oklahoma to $65^{\circ} \mathrm{F}$. through northern North Dakota. The lower elevation in the north counteracts the usual decrease in temperature with increase in latitude. These differences in temperature, as well as the length of the frost-free season (which is about 200 days in northern Oklahoma and I 20 days in North Dakota), have really little significance in terms of development of native grasses. They are important, however, as regards length of the grazing season. With adequate rainfall most grasses could thrive throughout the region, since over the entire area the growing season is long enough for them to mature. The longer warm growing season in the south is often shortened by periods of drought as compared with the more continuous although shorter 
growing season in the north. Thus in terms of grassland the climate of Dakota is not so different from that of Oklahoma.

Since crops may be selected for growth under different temperatures (for example, cotton and corn for the south and wheat and flax for the north) the temperature of the grassland is not a dominating factor in limiting its agricultural utilization. So far as the factor of temperature is concerned, as pointed out by Kincer, '23, the extension of the spring wheat belt through the western portions of the Dakotas and into eastern Montana and northeastern Wyoming is favored. So also is the production of other cool climate crops. However, the rather well defined latitudinal boundaries of the more eastern agricultural provinces would not be maintained in all cases even if the productive soils of the shortgrass plains were well watered. The northern half of the cotton belt, for example, could not be extended much further west than at present. The comparatively low summer temperatures and short growing season in northwestern Texas and extreme eastern New Mexico are unfavorable. This area would be thermally within the principal corn and wheat region. Thus the corn and wheat belt would extend westward to the foothills of the Rocky Mountains (Kincer, '23). Hence precipitation and not temperature is the limiting factor both to the degree of development of native grassland vegetation and the agricultural utilization of the region.

Many factors intervene to cause the amount of annual precipitation and its average annual distribution to be only very poor indicators of the amount of water available to plants. Chief among these are the kind of soil upon which the precipitation falls, the annual variation in amount of precipitation, the manner in which it falls, and the rapidity with which the moisture is again lost to the atmosphere either directly from the soil or through transpiring vegetation. The soil factor may be omitted for the present with the general statement that throughotit the grassland the soil is of such a nature that it has a good water retaining power after the precipitation enters it.

When the amount of precipitation is near the minimum required for crop growth (and this is the case throughout much of the grassland area) the annual variation in precipitation is a factor of great importance. In the northern portions of the grassland the annual variations are comparatively small and the precipitation of such a nature that most of the water enters the soil. But in the south annual variations are greater and the rainfall more frequently of a torrential nature and the amount of run-off water often great. All these factors are unfavorable to a luxuriant, stabilized vegetation as well as to permanent crop production.

The well recognized tendency for precipitation in the drier portions of the grassland to occur in cycles is familiar to all who have followed the agricultural development of this region since the passage of the homestead act in 1862 and the consequent inrush of settlers. Several successive years of comparatively generous rainfall have been followed in turn by several years 
with deficient moisture. The general movement of settlers has advanced and receded in almost perfect agreement with the wet phases and drought periods of the climatic cycle (Clements, '20). Abundant crops in years of ample moisture encouraged the western extension of the cultivated area, ensuing years of drought lead to crop failure and the wholesale abandonment of the region, to be followed by another influx of settlers during the wet phase. In more than one region of the west this process has been repeated three or four times. Hence the fact, as pointed out by Baker ('23), that the permanent use of land for crops seems to depend as much on the frequency and severity of the dry seasons as on the average yields obtained in a series of years.

The rate of evaporation from a free water surface during the growing season increases from about 30 inches in North Dakota to 60 inches in southwestern Kansas and eastern Colorado (Briggs and Belz, 'II). Since it requires nearly Io inches of rainfall to offset the extra 30 inches of evaporation, it is apparent why under 20 inches of rainfall in North Dakota tall-grass prairie is well developed and excellent crops of spring wheat are grown but under a similar rainfall in western Texas short-grass vegetation thrives and only the most drought enduring crops are cultivated.

Fourteen inches of precipitation in Montana, where temperatures and evaporation are low, are sufficient for a good growth of short grasses; I7 inches are required in Colorado, and $2 \mathrm{I}$ inches in Texas (Shantz, 'II). It requires 518 tons of water to produce a ton of alfalfa at Williston, North Dakota, 853 tons at Akron, Colorado, and 1005 tons at Dalhart, Texas (Briggs and Shantz, 'I7). Field studies by Cole and Mathews ('23) on the use of water by a crop of spring wheat show the rate to be twice as great in the south as in the north.

Although the isohyetal lines run more or less due north and south, the differences in the efficiency of the precipitation permit the mixed prairie vegetation to extend over most of the northern section of the grassland area in the United States. Conversely the short-grass plains vegetation in Colorado, Kansas, Texas, and Oklahoma pushes eastward with the southeasterly trending lines of efficient rainfall. Similarly, crop-producing areas of the north extend much farther westward and into much drier regions as measured by actual rainfall than in the far more arid southwest with equal total precipitation.

\section{SoIL}

The prairie climate has had a profound effect upon the soil of the grassland. As Marbut ('23) has pointed out, soils, like vegetation, show development. "The features assumed by the soil in its development from infancy, through youth, maturity, and old age, vary with the environment, especially with the climate and the natural vegetation." Hence, the broad general features assumed by the mature soil will be uniform throughout any given 
region with similar climate and vegetation, in this case throughout the grassland formation. The soil profile, that is its appearance in such a section as occurs in the walls of a trench, like the climax vegetation, is the summation of the climatic conditions over a long period of years. In fact both the vegetation and the soil profile are determined largely by the same factors which are chiefly the parent soil material and the climate.

Excavation of scores of trenches for root examinations, from the Missouri River to the Rocky Mountains, chiefly across the central portion of the grassland region, has furnished an excellent opportunity for an examination of soil profiles. If sandhill areas are disregarded, the soil is underlaid at a variable depth with a layer of accumulated carbonates except in the best watered eastern part where moisture penetration has been sufficient to leach away the carbonates. The carbonate layer is shallow in the fine sandy loams of the short-grass plains of Colorado where rainfall is light, run-off great, and evaporation and transpiration high, and where the heaviest rains of spring and summer have perennially moistened the soil to a depth of only i 2 to I 8 inches (Weaver and Crist, '22). The vigorous absorption by the rapidly growing short-grass vegetation prevents the water from penetrating deeper. In fact it seems probable that, had there been no vegetation to absorb the moisture, the layer of carbonate accumulation would never have developed. The depth of the carbonate layer is a measure of the depth of moisture penetration under the natural vegetation during all but exceptional years. When the vegetation is destroyed by cultivation the moisture penetration is considerably increased, even if the land is continuously cropped.

Eastward, under a gradually increasing precipitation, the carbonate layer becomes deeper. In the mixed prairie it occurs at levels varying from about 2 to 5 feet. Below the carbonate layer dry soil is found. Where the precipitation averages approximately 30 inches in eastern Kansas and Nebraska sufficient water penetration occurs, in spite of the enormous quantities removed by the vegetation-about a pound per square foot of soil area per day - so that the subsoil is permanently moist and the carbonate layer has quite disappeared. Thus the soil profile affords an indirect measure of the moisture during normal years, and, when properly interpreted along with the stabilized natural plant cover, affords a good index to the possibilities for crop production.

Thousands of soil samples from depths of 4 to io feet taken at weekly or fortnightly intervals during the past ten years, together with extensive root investigations, have revealed the following facts:

Short-grass plains vegetation characterizes areas where each year all of the available moisture is used by the plants. The depth of the carbonate layer delimits the area in which the absorption of water and nutrients usually occurs. Frequently the total available water supply is exhausted by early summer, in fact sometimes drought is so severe that even the rapidly matur- 
ing plains grasses do not ripen seed. The dominant plants have root systems well fitted for intensive absorption from the surface soil.

In the mixed prairie the carbonate layer still limits the depth of the prevailingly moist soil. Below this layer the soil is permanently dry. But the moist layer is of sufficient depth to promote a rather deeply rooting habit. and when the moisture in the surface layer is exhausted vegetation may draw upon that in the deeper soil. Thus conditions are such as to permit the growth and usually the maturity of a discontinuous cover of even the late blooming tall grasses.

Where the carbonate layer is deepest the tall-grass prairie begins. In eastern Nebraska and Kansas where the carbonate layer has disappeared the soil is permanently moist even beyond the roots of the plants, which frequently reach depths of 12 to 20 feet. The large soil volume thus afforded for absorption of water and nutrients undoubtedly accounts in a great measure for the luxuriant above-ground development. In the subclimax prairie eastward, the water relations are even more favorable.

The large amount of water absorbed and transpired by the native vegetation has only recently been measured. This averages about one pound of water per square foot of soil area per day throughout the long growing season in the tall-grass prairie, and a similar amount during a relatively short growing season in the short-grass plains (Weaver and Crist, '24). Thus late autumn drought in the east is quite as much due to the lavish expenditure of water by the luxuriant vegetation as to lack of rainfall.

Speaking broadly, the soils developed under the grassland climate, as modified by the activities of the grassland vegetation, are of varying depth, so far as availability to roots is concerned. Being unleached of their carbonates and thus free from acidity, as well as usually from excessive accumulations of alkali salts, they are of high productivity throughout.

The color of the soil (for example, from eastern Nebraska and Kansas westward) is dependent in a large measure upon the amount of humus afforded by the native vegetation. This, expressed in terms of the character and luxuriance of the vegetation, is dependent largely upon the amount of precipitation in relation to evaporation. As the carbonate layer rises, vegetation becomes scantier and the color of the soil becomes lighter. It varies from a black soil in eastern Nebraska and Kansas to a dark brown one in the central and western portions of these states. Further west in Colorado the color changes to a lighter brown. These colors correlate in general with the type and density of the vegetation.

The possibilities for crop production as indicated by the product of soil and climate during the past centuries - the climax plant communities-are as follows :

In the subclimax and other tall-grass prairie the presence of a continuous cover of tall, deeply rooted grasses indicates conditions favorable for the 
production of cultivated plants of similar habit, a fact fully substantiated by the excellent yields of wheat, oats, and corn. The continued growth of these grasses throughout the season, and the late period of flowering and seed production among most of them, indicate a long favorable growing season uninterrupted by a deficiency of soil moisture. The abundance of water in soil and subsoil is further attested by the presence of so many other herbs, many of which extend much deeper than the grasses and absorb the water that percolates downward through the surface soil. There is water enough for both grasses and legumes, as well as for composites, etc. The deeply rooted species have favorably modified the subsoil to great depths, enriching it with nitrogen, adding humus by root decay, as well as making it more porous, and as a result of absorption, vast stores of nutrients have been obtained from deeper soils and upon the death of the tops deposited in the surface soil. Thus the tall-grass prairie furnishes the most productive region for agriculture. It is in the western portion of this region that the transition from humid to arid conditions first becomes noticeable in the soil and in the systems of farming.

In the short-grass plains, which is the last frontier of agriculture in North America, the problem of land utilization is an exceedingly important one. The agricultural significance of the short-grass plains vegetation is distinct from that of the tall-grass prairie (Baker '23). It is a region of dry farming, grazing, and crop production under irrigation. The low stature of the plants is correlated with drought. Tall grasses with leaves exposed on elongated stems are not so well fitted to withstand desiccation nor are their roots so well adapted to absorb moisture from the surface few inches of soil. Roots fitted for surface absorption are an essential adaptation of plains grasses. In fact when either buffalo or grama grass grow in moist soil this root character almost entirely disappears.

Crop plants too, when grown here, must adapt themselves to these conditions although the removal of the sod and the maintaining of a cloddy mulch permit somewhat greater water penetration. Their response is similar to that of the native plants, i.e., low stature and shallow but widely spreading root systems. These are much more profusely branched than normally, many roots occurring just beneath the surface of the soil. Early maturing crops like winter wheat, although of uncertain but sometimes heavy yield, do best. Like the rapidly maturing plains grasses they may ripen seed before the soil moisture is exhausted. Many small grains and short-season corn are widely grown and the sorghums are well represented in the southern part of the area.

The high productivity of soil and subsoil is clearly shown where irrigation water is applied. In the moistened soil abundant crops of alfalfa, sugar beets, and other deeply rooted plants, under the otherwise favorable climate, produce excellent yields (Jean and Weaver, '24). However, owing to the 
uncertain distribution of precipitation, crop production without irrigation is always hazardous. Much of the area should always remain unbroken range land. Crops that develop late, such as maize, are best adapted to areas where deeper soil moisture is indicated by the abundance of the deeply rooted wild alfalfa and other legumes. Crop roots may here develop more normally and during favorable years, like the roots of the native species, secure enough moisture to escape drying out. Increased sandiness of the soil up to a certain limit is very favorable as the fertility still remains rather high. Such areas, most extensive on the eastern border of the short-grass plains, are at once delimited by the occurrence of deeply rooted tall grasses which thrive on the water penetrating through the surface mats of short-grass roots. Here the vegetation merges into mixed prairie, and possibilities for crop production are greatly increased (Weaver, '26).

In the mixed prairie the presence of short grasses with their root systems so excellently distributed for surface absorption, together with the marked development of the shallower portion of the root systems of many of the taller ones, points at once to their dependence upon moisture afforded the surface soils by light showers. The great masses of finely branched roots of both tall and short grasses occurring in the deeper soils indicate available water at these levels also. But the absence of a continuous cover of tall grasses shows at once a periodic deficiency in the water supply. The less abundant the late maturing tall grasses (under conditions undisturbed by grazing or otherwise) and the more abundant those of a shorter growing season, the greater the probability of midsummer soil water exhaustion and crop failure.

It is through the mixed prairie that the highly productive farm lands of the tall-grass prairie give way to the less productive ranch lands of the shortgrass plains. Corn growing becomes less important, listing becomes a common farm practice, and the relative acreage of wheat is greatly increased. Timothy and clover give way to wild grasses, brome grasses, alfalfa and sweet clover; the carrying capacity of pastures gradually decreases.

\section{Adapted Crops}

The fact has already been mentioned that the crops best adapted to the grassland climate are such grasses as corn, wheat, oats, sorghum, etc., and certain leguminous crops such as clovers and alfalfa, although cotton is grown extensively in the south and flax in the north.

A comparison of developing cereals, especially the smaller ones which grow under the widest range of environment, with those of native species, reveals much in common. This is not surprising when it is recalled that these crops, none of which except maize are native to America, have grown for long periods in regions with an environment not unlike that of our grasslands. 
There are many regions in the Old World where the climatic conditions are very similar to those of our semiarid grasslands and upon which civilized men have maintained themselves for thousands of years. Many varieties of drought resisting plants adapted to our grassland areas have been introduced from such places; such are Durum and Turkey Red wheat from the steppes of Crimea and adjacent regions. Kherson oats, brome grass, alfalfa, milo, Kafir, and other sorghums are further examples. Many failures of pioneer farmers in the drier sections of the west were due to their attempts to grow unadapted crops.

The introduction of hard Durum wheat from the Russian steppes made wheat growing possible in the grassland 300 miles farther west than formerly, and the introduction of hard red winter wheat resulted in the extension of wheat growing into areas where without it successful farming would have been much more difficult if indeed not impossible. The introduction of hardgrained winter varieties has added remarkably both to the certainty and value of the crop.

Not only have crops adapted to growth under a grassland climate been introduced but also often better varieties have been developed from them by selection and breeding. In fact nearly all of our common grains have been developed from plants which in their early history were adapted only to much more humid climates than those in which we now grow them. Some varieties of corn, for example, which have been developed in the more arid portions of the grassland are much better adapted to producing crops under severe conditions of drought than were the original stock from which they have descended. Milo, one of the grain sorghums, not so many years ago was a tall plant of irregular height and produced drooping heads, but a quite uniform dwarf strain with erect heads has been produced by systematic selection. A new strain of wheat, Kanred, produced only a few years ago (a pure line selection from Crimean-one of the hard red winter wheats of the Turkey type) is less subject to winterkilling, ripens a little earlier, is more rust resistant, and outyields the parent variety. In fact it is the most productive, hard red winter wheat for the Great Plains region (Clark and Salmon '2 I).

The general adaptation of cultivated plants to a region is controlled by a complex set of conditions by no means thoroughly understood. Nevertheless, the use of native vegetation for indicating possibilities of growth has proved very valuable in those areas where it has been most fully studied. A common feature of both native grasses and cereal crops is the rapidity of root development. In many of the prairie grasses this proceeds at the rate of half an inch a day for a period of several weeks, and similar growth rates are common among the small grains. They quickly establish contact with the moisture of the subsoil.

Prairie grasses often begin to tiller only 4 or 5 weeks after the seed has germinated. The new plantlets develop roots of their own simultaneously 
with the growth of the tops, but a brief period of drought at this critical time causes heavy losses (Clements and Weaver, '24). Similarly, the importance of favorable weather conditions for the tillering of the cereals is so great that it is recognized as a critical period in the life of the plant and one which has a marked effect upon yield.

The well-developed winter rosettes of wheat, with their store of food in stems and roots and their early growth and ripening the following season, have their counterpart in the needle grass (Stipa spartea), a widely distributed prairie species. Likewise, the phenomenon of the bunch habit among certain native species, which under more congenial growth conditions form a sod, is remarkably paralleled in the bunchy nature of dry-land wheat when compared with the uniform stands in the less arid portions of the grassland.

The enormous losses of prairie seedlings by winterkilling have only recently been appreciated as a result of experimental trials which show that a mortality of 50 to even 95 per cent frequently occurs. Similarly, low winter temperatures, especially temperature fluctuations, in the grassland climate are the cause for the frequent loss of the entire crop of fall sown grain, and rather sharply delimit the northward extension of the winter wheat belt.

Maize is a sun-loving crop of tropical origin. The great corn regions of the world are areas of continental climate. Bright sunshine, clear air, warm days and nights, and an abundance of soil moisture in a well drained soil are conducive to its best development. In the areas where summer temperatures are favorable for its growth, it thrives best and produces the greatest yields in that part of the grassland with the greatest rainfall. In terms of native grasses this means a deep, moist soil, a luxuriant growth, throughout the entire growing season, of tall, coarse vegetation which furnishes abundant organic material that decays without too rapid oxidation and maintains the productivity and tilth of the soil. Corn is a tall, luxuriant, coarsely rooted cereal which finds its greatest production on land formerly occupied by grasses of somewhat similar ecological requirements. Unlike wheat, it is a long season crop. It does best on deep, well drained soil with an adequate and uniform moisture supply throughout the growing season. Like the tall grasses it is an extravagant user of water, an acre of corn often presenting 4 acres of leaf surface for transpiration, and a full stand frequently using a quarter of an inch of water a day during its period of maximum demands (Burr and Russel, '25, and Kieselbach, 'I6). Clearly it is not so well adapted as the smaller cereals to the more arid sections of the grassland. By selection and breeding of drought resisting dwarf varieties its range has been pushed far westward. These short, adapted strains make yields more certain, but even with them crop failures are frequent. When the soil contains sufficient moisture to enable the seed to germinate and to permit the roots to become well established, and is thoroughly cultivated, dry weather 
usually has no harmful effect before the appearance of the tassels. But with the appearance of the tassels and the accompanying elongation of the stems, there is a great increase in the transpiring area. If the soil is dry the roots are often unable to supply moisture fast enough to compensate for that given off by transpiration. Drought at the critical time of anthesis may hasten the shedding of the pollen, if indeed the pollen has been formed, but delay the appearance of the silk. Thus proper fertilization is prevented and no amount of rain later will produce a good crop. Moreover, hot winds that often sweep over the level prairie may in a single day do serious injury by so greatly increasing the transpiration rate that the roots are unable to absorb sufficient water to adequately supply the plant, even though there be no actual deficiency of soil moisture.

Sorghum, introduced from the arid lands of Africa, has rapidly become an exceedingly important crop in the drier lands of the southwest, especially in Oklahoma. Although somewhat similar in general habit to corn, it is much better adapted to regions of low precipitation, deficient soil moisture, and hot winds. It grows slowly aboveground until an extensive root system has been established, thus leaving more water in the soil for the mature crop. It has been shown by Miller ('I6) that the root system is fully as deeply and wiclely spread as that of corn grown beside it, and, in addition, has approximately twice as many branches. Sorghums have a relatively small transpiring area (approximately only half that of corn), a very low water requirement, and, like many of the mixed prairie and plains grasses, an ability to remain in a more or less quiescent state during periods of drought. These qualities of drought resistance have done much to make sorghum the leading crop in the drier parts of the south and west portions of the grassland area.

Clover thrives best in a humid climate and where the winter and summer temperatures are not extreme. Timothy is unable to endure hot and dry summer weather. Hence these forage crops, affording high yields in the subclimax prairie and eastward, are replaced in the drier, tall-grass prairie and mixed prairie by alfalfa.

Alfalfa, like the native wild alfalfa (Psoralea tenuiflora) and many other prairie legumes, is well adapted to a dry climate where there is sufficient precipitation to maintain a moist subsoil. Although it requires more water than most crops, its ability to send down roots to great depths makes it very drought-resistant and a valuable crop for semiarid regions. Indeed the only large area of alfalfa grown under natural rainfall occurs in the grassland. Moreover, the many clear, dry days of summer are very advantageous in harvesting the crop. Since the plant cures slowly a good crop is frequently greatly damaged in harvesting in the humid sections of the country where rains are frequent. Although it is grown almost throughout the grassland area, its greatest center of production is in the tall-grass prairie of the eastern half of Nebraska and Kansas. This portion of the grassland has, broadly 
speaking, a non-acid soil. The precipitation has been insufficient to leach the subsoil of its abundant supply of carbonates.

In the tall-grass prairie and mixed prairie, under natural conditions, deeply rooted legumes grow relatively sparsely among the less deeply rooted grasses. Indeed the abundance of the leguminous and other non-grassy subdominants is largely regulated by the water supply not appropriated by the grasses. But under cropping conditions the deeply rooted alfalfa is grown in dense stands. Frequently it so thoroughly depletes the subsoil of its moisture that it is difficult or impossible to grow alfalfa, even after a lapse of ro to 5 years, on soils thus drained of their moisture (Russel, Unpubl.). Crops of maize, wheat or oats following alfalfa also often do poorly. When all the fields of a farm have once been enriched by crops of alfalfa and at the same time depleted of their subsoil moisture it seems probable that the question of maintaining soil productivity will become a very difficult one. Under the light rainfall of the mixed prairie of central Nebraska for example, there has been during the 20 to 50 years of cultivation, a gradual loss of organic matter from the soil, and the virgin productivity has been greatly depleted (Burr and Russel, '25). Not only has there been a gradual decline in yields but the soil is harder to work than formerly.

\section{Adequacy of Cultivation}

The first ecological problem in crop production is that of seed-bed preparation and planting in such a manner as to insure uniform germination and a good stand. Getting the crop started in the prairie soil, the surface of which is often dry, is important in agriculture. Among native plants, surface sowing of many species at ten different stations throughout the grassland during a period of four years, yielded a net establishment of only 28 per cent. Similarly, wheat, oats, or other cereals sowed broadcast and worked into a loose surface soil germinate non-uniformly and drought causes great losses. Hence a great advance was made in prairie agriculture with the introduction of the press drill. Grain that is drilled at a uniform depth in a firm seed-bed that is well compacted beneath will germinate better and the roots will have a more favorable environment for growth than grain that is broadcasted and worked into a loose soil.

The decreased rate of planting in the drier portion of the grassland is clearly indicated by the relative paucity and lessened luxuriance of the native species. Hence the western Kansas or Nebraska rancher, instead of seeding 6 pecks of wheat to the acre, often sows only about four. Water is the limiting factor to crop yield. Too thick sowing is a sure means of reducing the amount of water per plant, and consequently incurring the disastrous results of drought.

Protection against drought by water storage in the soil by methods of dry farming is very effective in many portions of the grassland. In western 
Nebraska this protection correlates very closely with the total available soil water within reach of the crop. During the sixteen years the North Platte Station has been in operation summer tillage has more than doubled the yield of winter wheat as compared with winter wheat following small grain, although during many years only enough water was accumulated to moisten the surface two or three feet of soil (Zook, '23).

Harmful results may be brought about by enriching the soil. The addition of manures rich in nitrogen promotes tillering, early luxuriant growth, and later exhaustion of the soil moisture. Many years of experimenting at stations bordering on the short-grass plains, have shown that yields are not increased by the addition of fertilizer. When manure is plowed under it often leaves the soil so loose as to dry quickly. The difficulty of putting the land to grass or legumes under a limited rainfall makes the maintenance of the organic content of the soil almost impossible, and it may be said that under such conditions the maintenance of soil productively is still unsolved. The loss of organic matter, moreover, makes the rainfall less efficient. Estimates carefully made from experimental data show that the loss of humus in one year through soil erosion under a precipitation of 26 inches is probably equivalent to a decrease of 6 inches in rainfall (Russel, Unpubl.). Soils that have lost humus are harder than formerly and in poorer tilth; they crack readily and expose large surfaces to evaporation.

Over much of the main wheat area the addition of straw is practically the only method of maintaining the humus supply of the soil. Investigations have shown that mulching with straw or mixing straw with the surface soil retards the growth of the crop, frequently delays ripening, and often materially reduces the yield. Various bacteria use the straw as a source of carbon, and the nitrates as a source of nitrogen. Thus the nitrates are transformed to organic nitrogenous material and for a time are lost as available food material for the growing crop (Albrecht, '22, Murray, '2I, Scott, '2I). But the practice of removing the grain and of burning the stacks of straw is not comparable to the prairie fire when the mineral nutrients removed from the soil were again scattered uniformly over its surface in the ash. How long will our grasslands continue to bear profitable crops under this treatment?

Plowing the wheat stubble soon after the crop is harvested has been fully demonstrated to be an excellent practice. It not only aids in keeping the water in the soil and making it more receptive to rainfall but promotes nitrification and thus furnishes a greater supply of nitrates to the wheat seedlings. It is very important that the fall sown grain should grow vigorously, produce a good root system, numerous tillers, and a reserve supply of food before the close of the growing season, for on this depends in a large measure its ability to survive the winter and make a rapid growth in spring. Well established winter wheat plants at Lincoln regained, in a period of less than two weeks 
and at an average daily temperature of only $42^{\circ} \mathrm{F}$., 60 per cent of the loss in dry weight which had occurred during the winter.

It is also of equal importance to sow spring grains early to promote a vigorous, deep root system and thus delay drought; to avoid, so far as possible. damage by insects and rusts; and especially to ripen the grain before it is injured by drought.

Winterkilling is not so much a question of freezing as one of drought. Low humidities of winter and spring, when the crop is not covered with snow, often accompanied by high winds (conditions so characteristic of the prairie climate), occurring at a time when the soil is very cold if indeed not frozen, are often disastrous to the plants. In the northern portion of the winterwheat belt the plants are frequently protected by drilling directly in the wheat stubble or between the rows of corn. A method of seeding the grain in furrows somewhat deeper and farther apart than those made with the ordinary wheat drill has many advantages. It not only promotes better and more certain germination when the surface soil is dry, but retains the snow which is otherwise blown from the field, and gives better protection to the grain from low temperatures during the winter. Moreover there is less injury from the heaving of the soil as a result of alternate thawing and freezing in spring. less injury from soil blowing and from drought (Salmon, '24).

Corn is surface planted in the more humid portion of the grassland but listed in the drier part where danger of drought is imminent. Listing gives better contact with the moist soil. Since the soil is not so rich as that nearer the surface and the soil temperature usually lower, the plants make a slower growth. The roots begin growth deeper in the soil, are further covered by each tillage and are not so subject to drought. Moreover, the plants stand up much longer against the force of the wind. I.isted sorghums also stand dry weather better and give larger yields where moisture is deficient during the latter part of the growing season. It would seem that corn drilled should have certain advantages over corn planted in hills. Each plant should receive more light and have a better root distribution. In cultivating, the roots would be less disturbed by cross cultivation but this advantage might be overbalanced by the weed factor, weeds being removed with greater difficulty from the surface drilled or listed row. Centuries of cultivation have rendered the corn plant intolerant of the proximity of other plants which shade it and compete with it for water and nutrients. This is especially noticeable in dry soils; if plenty of moisture is available pumpkins or soybeans may be grown under the corn in the same field.

The objects of tillage in well prepared soil, namely: keeping down weeds, preventing crusting of the surface and thus conserving the water by a surface mulch, and keeping the soil receptive to rainfall, are best accomplished by shallow cultivation. Often the greatest damage done by weeds is not from the absorption of water and nutrients but from the breaking of the corn roots 
during weeding. This is very detrimental in the drier soils, and is especially so during years of drought. Even in Missouri and Illinois decrease in yield of 8 to I 3 bushels per acre has resulted from deep cultivation (Mosier and Gustafson, 'I5). Deep cultivation not only breaks the roots but brings moist soil to the surface. Numerous experiments have shown that there is little value in late tillage. A network of roots so thoroughly appropriates the moisture that very little escapes by direct evaporation.

\section{SUMMARY}

The agricultural productivity of a region is conditioned by climate, topography and soil, adapted crops and adequacy of cultivation. The climate of the grassland is favorable throughout to the growth of various kinds of grasses and unfavorable to the growth of forests or other woody vegetation. Within this general climatic control differences in the amount of precipitation, and variations in the rate of evaporation result in differences in the type of grassland. The tall-grass prairie occupies the best watered, eastern portions of the grassland, extending from the Dakotas to Oklahoma. The shortgrass plains occupy the area in the west and southwest, i.e., western Nebraska and eastern Colorado southward, with the lowest efficient precipitation and the highest evaporation. Between the tall-grass prairie and the short-grass plains, the region of intermediate rainfall and evaporation, i.e., central Kansas and Nebraska, is covered with mixed prairie. Owing to decreased evaporation northwestward this association occupies practically all of the area between the Rocky Mountains and the tall-grass prairie. Temperatures of the grassland are sufficiently high so that they have no controlling effect upon the development of native vegetation. But even if the area were abundantly supplied with moisture throughout, the well defined latitudinal boundaries such as those of the more eastern agricultural provinces would in many cases not be maintained across the grassland because of high altitudes and resulting lower temperatures westward. Annual variation in the precipitation is a factor of extreme importance. This is less in the north, and the precipitation, 70-80 per cent of which falls in the summer, is of such a nature that little is lost in run-off. Evaporation also is relatively low. In the south annual variation is greater, the precipitation more often of a torrential nature, run-off higher, and evaporation very great. Thus mixed prairie, indicating greater possibilities for crop production, and extensive areas actually producing crops, occupy the northwest. The short-grass plains extend far eastward in the south where grazing and the growing of drought-resistant forage crops prevail.

A similarity of climate and vegetation have combined to produce similar mature soils throughout the grassland. The soil color and profile varies with decreased precipitation and less luxuriant vegetation from east to west. In the west, $e . g$., the short-grass plains of Colorado, it is light brown in color and 
underlaid at a depth of Io to 18 inches with a carbonate layer. Native vegetation must secure its water during the short growing season when the soil is moist above this layer. The soil is dark brown in the mixed prairie, water penetration deeper, and native and cultivated plants are more deeply rooted. The water supply, which is entirely above the carbonate layer at a depth of I. 5 to 5 feet, is usually exhausted by late summer. Here dry-land crops and dry-farming methods are used. Where the carbonate layer is deepest or has disappeared the soils are black in color, and both soil and deep subsoil are supplied with moisture. Here the deeply rooted, tall grasses of the prairie are found. This is also the best region for the growth of cultivated plants, and many humid climate crops and humid systems of farming prevail.

Cereal (grass) crops and certain legumes are best adapted to the grassland. Ecologically these have much in common with the native grasses. Aside from maize, practically all important crops grown in the grassland have been introduced from regions with a similar grassland climate. Successful agriculture has been made possible and profitable only by such introductions as Durum and Turkey Red wheat, sorghums, etc. By selection and breeding, crops even better adapted to a grassland climate have been produced, and agriculture in the prairie made more certain and more profitable. The larger cereal maize, like the taller grasses, is best developed in the eastern part of the grassland, the corn belt extending but little beyond the tall-grass prairie. Sorghum is an excellent crop for the drier, southwest, short-grass plains. Alfalfa replaces clover as a leguminous crop in all but the best watered portions of the grassland. It exhausts the water of the subsoil so thoroughly as to introduce puzzling agronomic problems.

Adequate cultivation is an important factor in a region of low precipitation and high evaporation. Planting the seed at a uniform depth and in close contact with moist soil is accomplished by the press drill. Storing water in the soil by dry-farming methods, by listing, and by decreasing the rate of seeding are effective protection against drought. Early fall plowing not only increases water storage but promotes nitrate accumulation. The problem of maintaining soil fertility in a region of low rainfall is of great importance and as yet unsolved. The problems of the agronomist should become more and more the problems of the ecologist, for agriculture is in a large part only the making of an environment conducive to the growth of plants.

\section{Literature Cited}

Albrecht, W. A. I922. Nitrate accumulation under straw mulch. Soil Science, I 4: 299-305.

Baker, O. E. I923. The agriculture of the great plains region. Annals Assoc. Amer. Geog. 13: ro9-167.

Briggs, L. J., and Belz, J. O. I9II. Dry farming in relation to rainfall and evaporation. U. S. Dep't. Agr., Bur. Plant Ind. Bull. 188. 
Briggs, L. J., and Shantz, H. L. I9I7. The water requirements of plants as influenced by environment. Second Pan-American Scientific Congress, Washington, D. C., Dec. 27, 1915-Jan. 8, I916.

Burr, W. W., and Russel, J. C. I925. Report of certain investigations on the central Nebraska supplemental irrigation project. Fifteenth Report of Department of Public Works, Nebraska, I923-24, pp. 199-240.

Carleton, M. A. I90o. The basis for the improvement of American wheats. U. S. Dep't. Agr. Div. Veg. Phys. and Path. Bull. 24.

Clark, J. A., and Salmon, S. C. 1921. Kanred wheat. U. S. Dep't. Agr., Dep't. Cir. I94.

Clements, F. E. I920. Plant indicators. Carnegie Inst. Wash. Pub. 290, p. I40, pp. $247-255$.

Clements, F. E., and Weaver, J. E. 1924. Experimental vegetation, the relation of climaxes to climates. Carnegie Inst. Wash. Pub. 355.

Cole, J. S., and Mathews, O. R. I923. Use of water by spring wheat on the great plains. U. S. Dep't. Agr., Dep't. Bull. Ioo4.

Jean, F. C., and Weaver, J. E. I924. Root behavior and crop yield under irrigation. Carnegie Inst. Wash. Pub. 357.

Kiesselbach, T. A. I9I6. Transpiration as a factor in crop production. Nebr. Agr. Exp. St. Res. Bull. 6.

Kincer, J. B. 1923. The climate of the great plains as a factor in their utilization. Annals Assoc. Amer. Geog. 13: 67-80.

Marbut, C. F. 1923. Soils of the great plains. Annals Assoc. Amer. Geog. 13: $4 \mathrm{I}-66$.

Miller, E. C. I9i6. Comparative study of the root systems and leaf areas of corn and the sorghums. Jour. Agr. Res., 6: 3II-332.

Mosier, J. G., and Gustafson, A. F. 1915. Soil moisture and tillage for corn. Ill. Agr. Exp. Sta., Bull. I8I.

Murray, T. J. I92I. The effect of straw on the biological soil processes. Soil Science, 12: 233-259.

Russel, J. C. Unpublished data, department of agronomy, University of Nebraska.

Salmon, S. C. 1924. Seeding small grain in furrows. Kans. Agr. Exp. Sta. Technical Bull. I3.

Scott, H. I921. The influence of wheat straw on the accumulation of nitrates in the soil. Jour. Am. Soc. Agron. I3: 233-258.

Shantz, H. L. I9I I. Natural vegetation as an indicator of the capabilities of land for crop production in the great plains area. U. S. Dep't. Agr., Bur. Pl. Ind. Bull. 2oI.

Shantz, H. L. I923. The natural vegetation of the great plains region. Annals Assoc. Amer. Geog. 13: 8I-Io7.

Weaver, J. E. I926. Root development of field crops. McGraw-Hill Book Co., New York.

Weaver, J. E., and Crist, J. W. I922. Relation of hardpan to root penetration in the great plains. Ecology, 3: 237-249.

Weaver, J. E., and Crist, J. W. 1924. Direct measurement of water loss from vegetation without disturbing the normal structure of the soil. Ecology, 5: $153-170$.

Zook, L. L. I923. Dry farming investigations at the Scottsbluff Substation. Nebr. Agr. Exp. Sta. Bull. I92. 